\title{
ASSESSMENT OF KNOWLEDGE AND ANXIETY LEVELS DUE TO COVID -19 PANDEMIC AMONG HEALTH CARE PROFESSIONALS AND GENERAL POPULATION OF INDORE CITY: ACROSS SECTIONAL STUDY
}

\author{
${ }^{1}$ Department of Oral Medicine\& Radiology, \\ College - Government College of Dentistry, Madhya Pradesh, INDIA \\ ${ }^{2}$ College - Department of Oral Medicine \& Radiology, \\ Swamy Devi dyal Dental College, Panchkula, Haryana, INDIA \\ ${ }^{3}$ College - Department of Oral Pathology\& Microbiology, \\ Government College of Dentistry, Indore, Madhya Pradesh, INDIA \\ ${ }^{4}$ College - Department of Prosthodontics, Index Institute of Dental Sciences, \\ Indore, Madhya Pradesh, INDIA \\ ${ }^{5}$ National Oral Health Program Centre for Dental Education and Research, \\ College - AIMS, New Delhi, INDIA
}

\begin{abstract}
BACKGROUND. COVID 19 pandemic has led to economic downturn worldwide, and it has negatively affected mental health of the health workers as well as the general population. The pandemic has created psychological impact in the minds of people that even after recovery from critical illness assessment of anxiety symptoms is necessary.

OBJECTIVE. This study was undertaken to assess the knowledge and anxiety levels among health care workers and non-medico/ general population of Indore, Madhya Pradesh.

METHODS. A descriptive, cross sectional study was conducted among 247 participants comprising of medical and dental professionals, paramedical staff and non medico/ general population of Indore city, India. The questionnaire was divided into three sections, the first section comprised questions pertaining to socio demographic characteristics, second section comprised ten questions pertaining to awareness and attitude towards preventive measures whereas the third section assessed anxiety levels by use of 21 item Depression, Anxiety, Stress Scale (DASS-21).

RESULTS. Participants of medical profession (50.2\%) outnumbered other participants; significant difference $(\mathrm{p}=0.001)$ was reported among dental professionals on answering minimum physical distance to be maintained. Anxiety scores were found to be low (92.7\%) and statistically significant association was seen between age of participants and anxiety levels $(\mathrm{p}=0.021)$.
\end{abstract}

CONCLUSION. Participants in the present study reported good knowledge regarding COVID-19 pandemic. Anxiety scores among the participants were found to be low.

Keywords: anxiety, COVID -19 , coronavirus, pandemic 


\section{INTRODUCTION}

COVID -19 is highly contagious infectious disease caused by novel coronavirus, Severe Acute Respiratory Syndrome Coronavirus-2 (SARS-CoV-2). Since its origin in late December 2019 in Wuhan, Hubei Province, China, virus has rapidly spread outside China, affecting over millions of people across the globe. ${ }^{1}$ World Health Organization (WHO) declared COVID -19 as Pandemic on March 11,2020, and due to its rapid transmission rate it has been suggested as sixth global health emergency of International concern. ${ }^{2}$ Novel Coronavirus belongs to family of $\beta$ coronaviridae, and specifically targets Angiotensin Converting enzyme 2(ACE2) receptors, profoundly present in the respiratory, cerebrovascular and salivary gland tissues. ${ }^{2,3}$ SARS - CoV -2 infection started as animal (bats ) to human transmission, followed by sustained human to human transmission by contact, aerosol / droplet transmission and touching of contaminated environmental surfaces. ${ }^{1}$ Health care professionals are at frontline in screening and examination of patients, and are at higher risk to acquire infection by physical contact, saliva and other body fluids. SARS-CoV -2 causes mild to severe pneumonia like illness and progression of infection eventually leads to Acute Respiratory Distress Syndrome (ARDS), multiorgan failure and finally death. ${ }^{4}$

As on July 11, 2020, India recorded 8,20,916 cases, with a single day spike of 27,114 cases and total number of deaths accounted to $22,123 .{ }^{6}$ Unfortunately, the ongoing pandemic is showing overwhelming daily rise in active cases, and has caused tremendous effect on the lifestyle of the people to a variable extent. To curb the spread, Government organizations globally reinforced strict measures of quarantine or self-isolation, these measures although essential but had made people to experience significant psychological distress in the form of anxiety, irritability, depression, insomnia and changes in concentration. The mental health problems are becoming a major concern; therefore it is utmost important to address the perceived stress related symptoms prevalent among the general population and the need of mental health care to improve the quality of life. ${ }^{7-10}$ As on July 7, Indore city has recorded 6,895 active cases, therefore the present study was conducted to evaluate the knowledge and level of anxiety prevalent in the health care professionals and nonmedico / general population of Indore city, Madhya Pradesh during the coronavirus pandemic.

\section{MATERIALS AND METHODOLOGY}

A descriptive, cross sectional study was conducted on health care professionals and general population of Indore city, India. The study population was categorised as medical professionals, non-medical personnel and para medical staff. Ethical clearance was obtained from the institutional ethical committee of Government Dental College Indore. The study was carried out in May-June 2020 using structured multiple choice online questionnaire divided into three sections, the first section comprised of questions pertaining to socio demographic characteristics such as age, gender, occupation, whether they belong to COVID 19 affected region /or containment zone and had any contact with COVID 19 positive patient. Second section comprised series of ten questions assessing the level of awareness and knowledge regarding SARS - $\mathrm{CoV} 2$ infection and general preventive measures adopted to reduce the transmission of infection and lastly the third section comprised of assessment of psychological status using well established 21 -item Depression, Anxiety and Stress Scale (DASS 21). ${ }^{9}$ Seven items of each component were scored on 4 point Likert Scale ranging from 0 ( did not apply to me at all), to 3 ( applied to me very much, or most of the time).Scores for depression, anxiety and stress items were summed up and multiplied by two. Based on the score obtained, the extent of the given emotion was classified as normal, mild, moderate, severe and extremely severe (Tab. I).

Questions of the survey were designed in English after reviewing pertinent literature and Centre of Disease Control (CDC) and WHO guidelines. Validation of survey content was verified by two experts $(n=2)$ from the field, who were oral medicine specialists with an experience of ten years and irrelevant or misleading questions were deleted from the final questionnaire. 247 participants with internet access and ability to understand English filled the questionnaire through Google form link sent via Whatsapp groups/emails. Informed consent was taken from all the study participants, anonymity was maintained to establish privacy and confidentiality of the information collected from the participants. Responses were made on a single Web page with one "submit" button that only allowed submissions through these unique links once and no option was available to edit the response once submitted.

Data collected was entered in Microsoft Excel and subjected to statistical analysis using Statistical package of social science (SPSS IBM version 20., Chicago,IL,USA). Descriptive statistics have been used to analyse the findings and frequency distributions of responses i.e. $\%$ are presented in form of bar and pie 
Table I. Depression, Anxiety and Stress Scale (DASS21) and Scoring

\begin{tabular}{|c|c|c|c|c|}
\hline Statement & $\begin{array}{c}\text { Not at all } \\
\text { bothered me }\end{array}$ & $\begin{array}{c}\text { Mildly, but } \\
\text { didn't bothered } \\
\text { me much }\end{array}$ & $\begin{array}{l}\text { Moderately, It } \\
\text { was pleasant at } \\
\text { times }\end{array}$ & $\begin{array}{c}\text { Severely, It } \\
\text { Bothered me } \\
\text { a lot }\end{array}$ \\
\hline 1.Numbness or Tingling & 0 & 1 & 2 & 3 \\
\hline 2.Feeling Hot & 0 & 1 & 2 & 3 \\
\hline 3. Wobbliness in legs & 0 & 1 & 2 & 3 \\
\hline 4. Unable to relax & 0 & 1 & 2 & 3 \\
\hline 5.Fear of worst happening & 0 & 1 & 2 & 3 \\
\hline 6. Dizzy or lightheaded & 0 & 1 & 2 & 3 \\
\hline 7.Heart pounding/racing & 0 & 1 & 2 & 3 \\
\hline 8. Unsteady & 0 & 1 & 2 & 3 \\
\hline 9. Terrified or afraid & 0 & 1 & 2 & 3 \\
\hline 10.Nervous & 0 & 1 & 2 & 3 \\
\hline 11. Feeling of choking & 0 & 1 & 2 & 3 \\
\hline 12. Hands trembling & 0 & 1 & 2 & 3 \\
\hline 13. Shaky / unsteady & 0 & 1 & 2 & 3 \\
\hline 14. Fear of losing control & 0 & 1 & 2 & 3 \\
\hline 15. Difficulty in breathing & 0 & 1 & 2 & 3 \\
\hline 16. Fear of dying & 0 & 1 & 2 & 3 \\
\hline 17. Scared & 0 & 1 & 2 & 3 \\
\hline 18.Indigestion & 0 & 1 & 2 & 3 \\
\hline 19. Faint / lightheaded & 0 & 1 & 2 & 3 \\
\hline 20.Face Flushed & 0 & 1 & 2 & 3 \\
\hline 21.Hot/Cold Sweats & 0 & 1 & 2 & 3 \\
\hline
\end{tabular}

\begin{tabular}{|c|c|}
\hline Rating & Score \\
\hline Normal & $0-7$ \\
\hline Mild & $8-9$ \\
\hline Moderate & $10-14$ \\
\hline Severe & $15-19$ \\
\hline Extremely Severe & $20+$ \\
\hline
\end{tabular}

responses for all questions on COVID 19; however, the greatest number of incorrect responses (38.5\%) were observed for question on minimum distance to be maintained between oneself and other person. On analysing individual responses for each question, it was found that $246(99.6 \%)$ participants were well aware that first case of COVID 19 infection was reported in Wuhan, China, 240 (96.0\%) participants sector charts. The level of significance was fixed at 5 $\%$ and $\mathrm{p}<0.05$ was considered statistically significant. Kolmogorov-Smirnov test and Shapiro -Wilks test was employed to test the normality of data. Chi square tests and Pearson's Correlation were performed for quantitative variables.

\section{RESULTS}

A total of 247 participants were included in the study, majority of the participants were female (58.3\%) in the age group of 21-30 years (39.3\%). Participants of medical profession (50.2\%) outnumbered other participants and a major number of participants in the study were in non-containment zone $(85.8 \%)$ with no previous contact with COVID positive patient (93.5\%) and with very low anxiety scores (92.7\%) (Tab. II). Tab.III shows that participants reported greater correct mentioned respiratory droplets as main mode of transmission, and 202 (81.8\%) reported fever, dry cough and tiredness as major symptoms of SARS CoV2 infection. On evaluation of responses pertaining to preventive and infection control measures, 220 (89.1\%) participants practiced regular hand hygiene, $152(61.5 \%)$ maintained physical distance between oneself and other person; however when awareness level was assessed, maximum incorrect responses $(38.5 \%)$ were observed for minimal physical distance required to be maintained as specified by WHO guidelines. 191 (77.3\%) reported correct responses for myths related to COVID 19 (Tab. III). On comparison among different professional groups, significant difference $(p=0.001)$ was reported among health care professionals on answering minimum physical distance to be maintained, with a greater proportion of paramedical staff reporting the incorrect responses 
Table II. Description of study participants based upon different characteristics

\begin{tabular}{|l|c|c|}
\hline \multicolumn{1}{|c|}{ Variable } & Category & Frequency \\
& & N $(\%)$ \\
\hline \multirow{2}{*}{ Age Group } & $20-31$ years & $97(39.3)$ \\
& $31-40$ years & $81(32.8)$ \\
& $41-60$ years & $7(25.1)$ \\
\hline \multirow{2}{*}{ Gender } & 61 years and above & $103(41.7)$ \\
\hline & Male & $144(58.3)$ \\
\hline Profession & Female & $124(50.2)$ \\
& Medical Professional & $110(44.5)$ \\
COVID Zone & Non Medical Professional & $13(5.3)$ \\
\hline Previous Contact with any COVID & Para Medical Professional & $35(14.2)$ \\
positive patient & Containment & $212(85.8)$ \\
\hline & Non Containment & $16(6.5)$ \\
Beck Anxiety Scores & Yes & $231(93.5)$ \\
\hline
\end{tabular}

Table III. Evaluation of participant responses to questionnaire on knowledge related to COVID 19

\begin{tabular}{|c|c|c|}
\hline Question & Responses & $\mathrm{N}(\%)$ \\
\hline $\begin{array}{l}\text { First case of Corona virus infection } \\
\text { was reported in }\end{array}$ & $\begin{array}{l}\text { Correct Response } \\
\text { Incorrect Response }\end{array}$ & $\begin{array}{c}246(99.6) \\
1(.4)\end{array}$ \\
\hline $\begin{array}{l}\text { Severe Corona virus infections are } \\
\text { primarily known to cause }\end{array}$ & $\begin{array}{l}\text { Correct Response } \\
\text { Incorrect Response }\end{array}$ & $\begin{array}{c}246(99.6) \\
1(.4)\end{array}$ \\
\hline Main mode of transmission of virus is & $\begin{array}{l}\text { Correct Response } \\
\text { Incorrect Response }\end{array}$ & $\begin{array}{l}237(96.0) \\
10(4)\end{array}$ \\
\hline $\begin{array}{l}\text { Most common symptoms of COVID } \\
-19 \text { include }\end{array}$ & $\begin{array}{l}\text { Correct Response } \\
\text { Incorrect Response }\end{array}$ & $\begin{array}{c}202(81.8) \\
45(18.2)\end{array}$ \\
\hline $\begin{array}{l}\text { Which among the following are more } \\
\text { likely to develop serious illness }\end{array}$ & $\begin{array}{l}\text { Correct Response } \\
\text { Incorrect Response }\end{array}$ & $\begin{array}{c}198(80.2) \\
49(19.8)\end{array}$ \\
\hline $\begin{array}{l}\text { What is the preferred method for hand } \\
\text { hygiene }\end{array}$ & $\begin{array}{l}\text { Correct Response } \\
\text { Incorrect Response }\end{array}$ & $\begin{array}{l}220(89.1) \\
27(10.9) \\
\end{array}$ \\
\hline $\begin{array}{l}\text { Which of the following hand hygiene } \\
\text { action prevents transmission of virus } \\
\text { to the health care workers }\end{array}$ & $\begin{array}{l}\text { Correct Response } \\
\text { Incorrect Response }\end{array}$ & $\begin{array}{l}220(89.1) \\
27(10.9)\end{array}$ \\
\hline $\begin{array}{l}\text { How much minimum distance should } \\
\text { be maintained between oneself and } \\
\text { other person }\end{array}$ & $\begin{array}{l}\text { Correct Response } \\
\text { Incorrect Response }\end{array}$ & $\begin{array}{l}152(61.5) \\
95(38.5)\end{array}$ \\
\hline $\begin{array}{l}\text { Which among the following is not a } \\
\text { myth related to COVID- } 19\end{array}$ & $\begin{array}{l}\text { Correct Response } \\
\text { Incorrect Response }\end{array}$ & $\begin{array}{l}191(77.3) \\
56(22.7)\end{array}$ \\
\hline $\begin{array}{l}\text { What should be done during home } \\
\text { quarantine }\end{array}$ & $\begin{array}{l}\text { Correct Response } \\
\text { Incorrect Response }\end{array}$ & $\begin{array}{c}246(99.6) \\
1(.4)\end{array}$ \\
\hline
\end{tabular}

(Tab. IV). Assessment of Anxiety levels revealed low anxiety scores (0-10) among majority of the participants (92.7\%). A comparative evaluation of different levels of anxiety among participants reported significant differences in the levels of anxiety only with age group of the participants $(p=0.021)$. No significant differences between gender, profession, containment zones and contact with COVID 19 positive patients with levels of anxiety were observed (Tab. V). Corrrelation between the level of knowledge about COVID 19 and level of anxiety revealed statistically insignificant negative correlation between the anxiety levels and knowledge regarding COVID -19 (Tab. VI). 
Table IV. Comparative evaluation of knowledge assessment based on participant's profession

\begin{tabular}{|c|c|c|c|c|}
\hline Question & Profession & Yes & No & $\mathrm{p}$ value \\
\hline $\begin{array}{l}\text { First case of Corona virus infection was reported } \\
\text { in }\end{array}$ & $\begin{array}{l}\text { Medical Professional } \\
\text { Non Medical Professional } \\
\text { Para Medical Professional }\end{array}$ & $\begin{array}{c}123 \\
110 \\
13\end{array}$ & 1 & .608 \\
\hline $\begin{array}{l}\text { Severe Corona virus infections are primarily } \\
\text { known to cause }\end{array}$ & $\begin{array}{l}\text { Medical Professional } \\
\text { Non Medical Professional } \\
\text { Para Medical Professional }\end{array}$ & $\begin{array}{c}124 \\
109 \\
13 \\
\end{array}$ & 1 & .535 \\
\hline Main mode of transmission of virus is & $\begin{array}{l}\text { Medical Professional } \\
\text { Non Medical Professional } \\
\text { Para Medical Professional }\end{array}$ & $\begin{array}{c}121 \\
104 \\
12\end{array}$ & $\begin{array}{l}3 \\
6 \\
1\end{array}$ & .396 \\
\hline Most common symptoms of COVID -19 include & $\begin{array}{l}\text { Medical Professional } \\
\text { Non Medical Professional } \\
\text { Para Medical Professional }\end{array}$ & $\begin{array}{c}119 \\
107 \\
11\end{array}$ & $\begin{array}{l}5 \\
3 \\
2\end{array}$ & .091 \\
\hline $\begin{array}{l}\text { Which among the following are more likely to } \\
\text { develop serious illness }\end{array}$ & $\begin{array}{l}\text { Medical Professional } \\
\text { Non Medical Professional } \\
\text { Para Medical Professional }\end{array}$ & $\begin{array}{c}101 \\
92 \\
9 \\
\end{array}$ & $\begin{array}{c}23 \\
18 \\
4 \\
\end{array}$ & .584 \\
\hline What is the preferred method for hand hygiene & $\begin{array}{l}\text { Medical Professional } \\
\text { Non Medical Professional } \\
\text { Para Medical Professional }\end{array}$ & $\begin{array}{l}95 \\
91 \\
12\end{array}$ & $\begin{array}{c}29 \\
19 \\
1\end{array}$ & .267 \\
\hline $\begin{array}{l}\text { Which of the following hand hygiene action } \\
\text { prevents transmission of virus to the health care } \\
\text { workers }\end{array}$ & $\begin{array}{l}\text { Medical Professional } \\
\text { Non Medical Professional } \\
\text { Para Medical Professional }\end{array}$ & $\begin{array}{c}109 \\
98 \\
13\end{array}$ & $\begin{array}{l}15 \\
12\end{array}$ & .413 \\
\hline $\begin{array}{l}\text { How much minimum distance should be } \\
\text { maintained between oneself and other person }\end{array}$ & $\begin{array}{l}\text { Medical Professional } \\
\text { Non Medical Professional } \\
\text { Para Medical Professional }\end{array}$ & $\begin{array}{c}63 \\
82 \\
7\end{array}$ & $\begin{array}{c}61 \\
28 \\
6\end{array}$ & $\begin{array}{c}.001^{*} \\
(\mathrm{~s})\end{array}$ \\
\hline $\begin{array}{l}\text { Which among the following is not a myth related } \\
\text { to COVID- } 19\end{array}$ & $\begin{array}{l}\text { Medical Professional } \\
\text { Non Medical Professional } \\
\text { Para Medical Professional } \\
\end{array}$ & $\begin{array}{c}95 \\
89 \\
7 \\
\end{array}$ & $\begin{array}{c}29 \\
21 \\
6 \\
\end{array}$ & .203 \\
\hline What should be done during home quarantine & $\begin{array}{l}\text { Medical Professional } \\
\text { Non Medical Professional } \\
\text { Para Medical Professional } \\
\end{array}$ & $\begin{array}{c}124 \\
109 \\
13\end{array}$ & $\begin{array}{l}0 \\
1 \\
0\end{array}$ & .535 \\
\hline
\end{tabular}

Table V. Comparative evaluation of Anxiety level among participants with different characteristics

\begin{tabular}{|c|c|c|c|c|c|}
\hline Variable & Categories & $\begin{array}{l}\text { Very Low } \\
\text { Anxiety }\end{array}$ & $\begin{array}{l}\text { Moderate } \\
\text { Anxiety }\end{array}$ & $\begin{array}{c}\text { Potential Cause } \\
\text { of Concern }\end{array}$ & $\mathrm{p}$ value \\
\hline Age Group & $\begin{array}{c}\text { 20- } 31 \text { years } \\
31-40 \text { years } \\
41-60 \text { years } \\
61 \text { years and above }\end{array}$ & $\begin{array}{c}85 \\
78 \\
60 \\
6\end{array}$ & $\begin{array}{l}10 \\
2 \\
2 \\
0\end{array}$ & $\begin{array}{l}2 \\
1 \\
0 \\
1\end{array}$ & $\begin{array}{c}.021 * \\
(\mathrm{~s})\end{array}$ \\
\hline Gender & $\begin{array}{c}\text { Male } \\
\text { Female }\end{array}$ & $\begin{array}{c}98 \\
131\end{array}$ & $\begin{array}{c}4 \\
10\end{array}$ & $\begin{array}{l}1 \\
3\end{array}$ & .457 \\
\hline Profession & $\begin{array}{c}\text { Medical } \\
\text { Non Medical Para } \\
\text { Medical } \\
\end{array}$ & $\begin{array}{c}112 \\
106 \\
11 \\
\end{array}$ & $\begin{array}{c}10 \\
2 \\
2 \\
\end{array}$ & $\begin{array}{l}2 \\
2 \\
0\end{array}$ & .143 \\
\hline Zone & $\begin{array}{c}\text { Containment } \\
\text { Non Containment }\end{array}$ & $\begin{array}{c}31 \\
198\end{array}$ & $\begin{array}{c}2 \\
12 \\
\end{array}$ & $\begin{array}{l}2 \\
2\end{array}$ & .117 \\
\hline $\begin{array}{l}\text { Contact with } \\
\text { Covid Patient }\end{array}$ & $\begin{array}{l}\text { Yes } \\
\text { No }\end{array}$ & $\begin{array}{c}15 \\
214\end{array}$ & $\begin{array}{c}0 \\
14\end{array}$ & $\begin{array}{l}1 \\
3\end{array}$ & .198 \\
\hline
\end{tabular}


Prashanthi Reddy, Ravleen Nagi et al.

Table VI. Correlation between knowledge about COVID 19 and level of anxiety

\begin{tabular}{|c|c|c|c|}
\hline \multicolumn{2}{|c|}{} & \multirow{2}{*}{ Knowledge } & Anxiety \\
\hline \multirow{2}{*}{ Knowledge } & Correlation & 1 & -.105 \\
\cline { 2 - 2 } & p value & -.105 & .101 \\
\cline { 2 - 4 } & Correlation & .101 & 1 \\
\cline { 2 - 4 } Anxiety & p value & 105 \\
\hline
\end{tabular}

\section{DISCUSSION}

COVID 19 outbreak may be stressful for people, and has provoked fear and anxiety in both adults and children. According to reports, this pandemic is yet not over, and due to this people are becoming more fearful about thought of further dissemination of the infection. ${ }^{8,9}$ In consideration to above, this study was undertaken to assess the knowledge and anxiety levels due to COVID 19 pandemic among health care professionals and non medico/ general population of Indore city. Inhalation of respiratory droplets containing infectious particles is the most common route of infection, however viral particles have been found to remain viable on environmental surfaces for hours or days, and person can get an infection by touch of these surfaces and further touching of their mouth, nose or both by soiled hands. Therefore CDC has provided Interim Infection Prevention and Control recommendations to slow down the spread of infection locally and across the country and worldwide, and according to them social distancing, and quarantine or self-isolation are an effective measures. ${ }^{8,11}$

In our survey although participants were well aware of preventive protocols, but maximum number of incorrect responses (38.5\%) were observed for minimal physical distance to be maintained between oneself and nearby person which may be due to frequent face to face communication as most of our participants were medical professionals (50.2\%) who are actively involved in screening of patients at various health care centres. On comparison among professional groups, awareness was found low in nonmedico group, similar findings were observed in a study by Modi et a ${ }^{12}$ and they suggested that although non medico staff was not directly involved with patient screening, but they may be having patient contact at some point of time in health care setting and are at risk of being infected.

WHO has recommended regular washing of visibly soiled hands with soap and under running water for at least 20 seconds as an effective measure to reduce spread, but if hands are deeply soiled they should be washed with warm water and soap. CDC has recommended use of alcohol-based hand rub (ABHR) containing at least $60 \%$ to clean hands that are not visibly soiled, ABHR inactivates SARS CoV 2 and has better compliance than hand washing. ${ }^{12}$ In this study, $89.1 \%$ participants cleaned their hands after touching or on an exposure to body fluids. Similar results were observed by Jemal S in Ethiopian population in which $65.93 \%$ of heath care professionals had good knowledge about hand washing in prevention of transmission of infection. ${ }^{13}$ In another study, Modi et $\mathrm{a}^{12}$ found that $52.5 \%$ of responders were aware of the preferred hand hygiene method for visibly soiled hands and they emphasized the need of educational and training programs for health care professionals on COVID 19.

Besides preventive and infection control measures, it is important to assess the anxiety levels as due to rapidly progressing pandemic and extended lockdown, as a result Indian population has faced both economic and financial difficulties. In addition strict implementation of self-isolation or quarantine, and limitation of outward movement had made many people feel lonely and most of them have been found to succumb to use of tobacco products or alcohol to relieve stress. Studies have shown that there is increased prevalence of worry or stress due to coronavirus infection in people with poor health status with medical morbidities. ${ }^{5,7}$ In consideration to this, on 24 March 2020, Government of India in collaboration with National Health Institutes has launched helpline numbers to provide psychological counselling to cope with stress. Despite above efforts, people are overwhelmed with future impact of this global pandemic which is still in progression. ${ }^{14}$ Varshney et al ${ }^{15}$ found high anxiety scores $>24$ for Indian population, and they concluded that higher psychological impact was associated with younger age, female gender and medical comorbidities. Lai et a ${ }^{16}{ }^{1}$ in their study observed high anxiety scores in health care workers that ranged from 18 to 21 . In another study by Roy et a ${ }^{17}$ more than $80 \%$ people were found to be preoccupied by thoughts of COVID 19 pandemic and the need to address the perceived mental health care. In consideration to this, Government and other legal agencies should encourage online or smart phone-based psychoeducation and psychological interventions among adolescents and elderly people with medical comorbidities to reduce the anxiety associated symptoms. ${ }^{18}$ Social integration 
with practice of physical distancing and wearing of protective mask, can reduce stress by mitigating of negative emotions that may occur by prolonged duration of self-isolation. ${ }^{7,10}$ The present study was conducted when active cases were at peak in Indore city and country was in lockdown period, most of the participants $(92.7 \%)$ showed low anxiety scores, and experienced no symptoms of anxiety which may be due to positive mental health related lifestyle such as regular exercise, relaxation or increase support and care of family members during pandemic, our results were comparable to Modi et al ${ }^{12}$ and Tan et al. ${ }^{19}$

Studies have found influence of gender and profession on the mental health of an individual., ${ }^{72}$ Liang et $\mathrm{al}^{7}$ suggested that both men and women show stress symptoms and adopt different coping strategies to overcome stress. According to study by El-Zoghby et $\mathrm{al}^{20}$ females, married and young individuals feel more apprehensive and helpless due to pandemic and suggested both gender and marital status as key indicators of negative mental health. Although anxiety is more prevalent in women, but crisis has increased prevalence of anxiety in males due to increasing financial pressure or reduction of job opportunities. As per profession is concerned, it has been suggested that health care professionals exhibit avoidance behaviour after quarantine, they think more of SARS CoV 2, and are more concerned about cross infection among themselves and patients. ${ }^{21,22}$ Suryavanshi et $\mathrm{al}^{21}$ suggested that work environment stressors were associated with $46 \%$ increased risk of combined anxiety and depression and more than 50\% health care professionals have been found to have low quality of life due to a negative impact of pandemic. In the present study significant differences were found in relation to only age of the participants $(p=0.021)$, and more studies should be carried out to validate the association of other variables ;gender and profession with the anxiety levels.

Recent reports have shown several misconceptions about COVID 19, such as contracting infection from pets mainly dogs and cats, food or packaging from grocery stores, virus spreads through public water supply, by consumption of chicken, by mosquito bite, and religious gatherings. Currently there is no clear cut evidence in support of above misconceptions, increased use of social media such as face book, what's up, you tube to update themselves during lockdown period have been found and as a result people are believing in misconceptions or fake corona news. ${ }^{23}$ In the present study, participants had adequate knowledge about corona virus infection facts except minimum distance to be maintained between oneself and nearby person. The major limitation was limited sample size and unequal distribution of the study samples in different groups due to stringent inclusion criteria of participants with capacity to understand English language.

To conclude, the present study reported low anxiety scores among majority of participants which may be due to positive mental health related lifestyle such as regular exercise, relaxation or increase support and care of family members during pandemic. Although Indore population experienced reduced symptoms of anxiety, future studies on large scale population should be conducted taking into account gender, profession, and regions with high number of positive cases.

\section{REFERENCES}

1. Peng $\mathrm{X}, \mathrm{Xu} \mathrm{X}, \mathrm{Li}$ Y,Cheng L, Zhou X, Ren B. Transmission routes of $2019-\mathrm{nCoV}$ and controls in dental practice. Int J Oral Sci 2020;12:1-6.

2. Yoo JH. The fight against the $2019-\mathrm{nCoV}$ outbreak: an arduous march has just begun. J Korean Med Sci 2020;35:e56.

3. Shereen MS, Khan S,Kazmi A, Bashir N, Siddique R. COVID 19 infection: origin, transmission and characteristics of human coronaviruses. J Adv Research 2020;24:91-8.

4. Wang L, Wang Y, Ye D,Liu Q. Review of the novel coronavirus (SARS CoV 2) based on current evidence. Int J Antimicrob Agents. 2020;55:105948.

5. $\mathrm{Wu} \mathrm{Z}$, McGoogan JM. Characteristics of and Important Lessons From the Coronavirus Disease 2019 (COVID-19) Outbreak in China. J Am Med Assoc2020;323:1239-42.

6. Swati S. Coronavirus Live Updates. Available from: https://www.ndtv.com/india [Accessed 11 July 2020].

7. Laing L, Gao T, Ren H, Cao R,Qin Z, Hu Y, et al. Post-traumatic stress disorder and psychological distress in Chinese youths following the COVID-19 emergency. J Health Psychol 2020;25:1164-75.

8. Brooks SR, webster RK,Smith LE,Woodland L,Wessley S, Greenberg N, et al. The psychological impact of quarantine and how to reduce it: rapid review of the evidence.Lancet 2020;395:912-20.

9. Osman A,Wong JL, Bagge CL, Freedenthal S, Guiterrez PM, Lozano G. The Depression Anxiety Stress Scales-21 (DASS-21): Further Examination of Dimensions, Scale Reliability, and Correlates. J Clin Psychol $2012 ; 68: 1322-38$

10. Wu PE, Styra R, Gold WL. Mitigating the psychological effects of COVID19 on health care workers. Canadian Med Assoc J 2020;19245960.

11. Zhang Y,Ma ZF. Impact of the COVID-19 Pandemic on Mental Health and Quality of Life among Local Residents in Liaoning Province, China: A CrossSectional Study. Int J Environ Res Public Health 2020, 17:2381; doi:10.3390/ijerph17072381. 
12. Modi PD,Nair G,Uppe A, Modi J,Tuppekar B,Gharpure AS, et al. COVID-19 Awareness Among Healthcare Students and Professionals in Mumbai Metropolitan Region: A QuestionnaireBased Survey. Cureus $2020 ; 12:$ e7514.

13. Jemal S. Knowledge and Practices of Hand Washing among Health Professionals in Dubti Referral Hospital, Dubti, Afar, Northeast Ethiopia. Adv Preventive Med 2018 https://doi. org/10.1155/2018/5290797

14. Economic Times. Government launches helpline for mental health issues during lockdown. Availablefrom:https://economictimes.indiatimes. com/[Accessed 29 $9^{\text {th }}$ March, 2020].

15. Varshney M, Parel JT, Raizada N,Sarin SK. Initial psychological impact of COVID-19 and its correlates in Indian Community: An online (FEELCOVID) survey. PLoS ONE 2020;15: e0233874. https://doi.org/10.1371/journal.pone.0233874.

16. Lai J, Ma S, Wang Y, Cai Z, Hu J, Wei N, etal. Factors associated with mental health outcomes among health care workers exposed to coronavirus disease 2019.J Am Med Assoc 2020; ;3:e203976. doi:10.1001/jamanetworkopen.2020.3976

17. Roy D, Tripathy S, Kar SK, Sharma N, Verma SK, Kaushal V. Study of knowledge, attitude, anxiety $\&$ perceived mental healthcare need in Indian population during COVID-19 pandemic. Asian J Psychiatr 2020;51.

18. Rajderkar SS, Kendre GV. Assessment of psychological stress situation and study of awareness during corona virus disease (COVID19) pandemic among general population in Maharashtra. Int J Multidiscip Curr Educ Res 2020;2:59-66.

19. Tan BYQ, Chew NWS, Lee GKH, Jing M, Goh Y, Yeo LLL, et al. Psychological impact of the COVID -19 Pandemic on Health Care workers in Singapore. Annals Int Med 2020; https:/doi. org/10.7326/M20-1083.
20. El-Zoghby SM, Soltan EM, Salama HM. Impact of the COVID-19 Pandemic on Mental Health and Social Support among Adult Egyptians. J Community Health 2020;45:689-95.

21. Suryavanshi N, Kadam A, Dhumal G, Nimkar S, Mave V,Gupta A, et al. Mental health and quality of life among healthcare professionals during the COVID-19 pandemic in India. Brain Behaviour 2020;00:e01837.

22. Zurcher SJ, Kercksiek P, Adamus C, Burr C, Lehmann AI, Huber FK, et al. Prevalence of Mental Health Problems During Virus Epidemics in the General Public, Health Care Workers and Survivors: A Rapid Review of the Evidence

23. Sarla GS. COVID 19: Myths and Facts Research \& Review: Management Emerg Trauma Nurs 2020;2: 5-8.

\section{Conflicts of Interest}

Authors declare "no conflict of Interest"

Funding Sources: None

Received: 29.07.2020

Accepted for publication: 1.12.2020

\section{Address for correspondence:}

Dr Prashanthi Reddy

Designation - Reader, Department of Oral Medicine\&

Radiology

College - Government College of Dentistry

361, Suniket Apartment, Khajrana Main Road

Shree Nagar Extension, Indore- 452001

Madhya Pradesh, INDIA

Phone number- +91 9926430661

email id - drprashanthireddy@gmail.com 